\title{
Physical controls of food supply to benthic filter feeders in the Menai Strait, UK
}

\author{
J. F. Tweddle ${ }^{1,2}$, J. H. Simpson ${ }^{1, *}$, C. D. Janzen ${ }^{1,3}$ \\ ${ }^{1}$ School of Ocean Sciences, University of Wales, Bangor, Menai Bridge, Anglesey LL59 5AB, UK \\ ${ }^{2}$ Present address: Southampton Oceanography Centre, University of Southampton, Waterfront Campus, European Way, \\ Southampton SO14 3ZH, UK \\ ${ }^{3}$ Present address: School of Marine Sciences, 5741 Libby Hall, Room 214, University of Maine, Orono, Maine 04469, USA
}

\begin{abstract}
We report herein a study of the role of hydrodynamics in controlling the food supply to benthic filter feeders in the Menai Strait, a narrow channel between the island of Anglesey and north Wales, UK, which is tidally energetic with pronounced residual flow $\left(\sim 350\right.$ to $\left.800 \mathrm{~m}^{3} \mathrm{~s}^{-1}\right)$. A comparison between the cycle of chlorophyll concentrations in water above an extensive, commerciallyexploited, mussel bed (Mytilus edulis L.) and the corresponding cycle over a control site showed clear evidence of the influence of horizontal tidal advection on food supply. Consumption of phytoplankton by filtration over the mussel bed reduced concentrations and resulted in a pronounced horizontal gradient $\left(\sim 4.4 \times 10^{-4} \mathrm{\mu g} \mathrm{l}^{-1} \mathrm{~m}^{-1}\right)$. Losses to filtration appeared to be compensated through transport of plankton-rich water into the strait by the large residual flow while advection of the gradient by the tidal current resulted in large oscillations in chlorophyll a (chl a) concentration, with an amplitude of $\sim 50 \%$ of the mean. An analytical model of advection and consumption reproduced these features of the observed chl a cycle over the mussel bed. The strong tidal flow maintained a high level of turbulence, so that the water column was generally well mixed vertically. Depletion of phytoplankton in the bottom boundary layer was, therefore, not present for most of the tidal cycle but on 2 occasions, when the observed Reynolds stress was close to zero at slack water, we did observe significant depletion by up to $\sim 2 \mu \mathrm{g} \mathrm{l}^{-1}$ at $1 \mathrm{~m}$ above the bed. This depletion is interpreted as the effect of mussel feeding briefly out-competing the supply of phytoplankton by vertical diffusion for the period of low turbulence. Assuming a steady state, we estimated the total supply of phytoplankton imported into the strait $\left(\sim 9.0 \mathrm{t} \mathrm{C} \mathrm{d}^{-1}\right)$ and the amount consumed by filter feeders in the area of the mussel bed $\left(\sim 4.5 \mathrm{t} \mathrm{C} \mathrm{d}^{-1}\right)$.
\end{abstract}

KEY WORDS: Concentration boundary layer - Turbulent transport - Mytilus edulis - Menai Strait · Residual flow $\cdot$ Mussel nutrition

\section{INTRODUCTION}

\section{Background}

The physical processes of advection and diffusion play a crucial role in the supply of food to sessile filter feeders, and consumption by these organisms leads to steep concentration gradients. Filter feeders such as corals (Fabricius \& Dommisse 2000) and bivalves (Cohen et al. 1984), including Mytilus edulis (Wildish \& Kristmanson 1984), have been shown to diminish phyto- plankton concentrations as water passes over them. This leads to horizontal gradients in phytoplankton concentration, with higher concentrations upstream of the suspension feeders, and lower concentrations downstream. Concentration gradients may lead to food limitation downstream of the leading edge of the mussel bed.

Pronounced vertical phytoplankton concentration gradients may also result from intensive filter feeding, as has been found in a variety of environments, such as lakes (Ackerman et al. 2001), bays (Cloern 1982) and 
in shallow seas (Yahel et al. 1998). Many filter feeders are sedentary benthic dwellers and, as such, have access only to water immediately adjacent to the bed. Replenishment of the filtered water, through currents and/or turbulent transport, at a rate slower than the rate of consumption of phytoplankton, can result in depletion of phytoplankton at or near the bed, leading to a concentration boundary layer (Wildish \& Kristmanson 1984, O'Riordan et al. 1993).

Phytoplankton, which by definition are at the mercy of prevailing currents and turbulence, may be moved by advection from upstream and by diffusion from the euphotic zone (where primary production takes place) into the vicinity of the bed where they are available to the benthos. This transport into and through the boundary layer is crucial in supplying the benthos with food (Wolff et al. 1975, Fréchette \& Bourget 1985, Fréchette et al. 1989, Ackerman 1999), and consequently the intensity of turbulence is an important factor in controlling the downward flux of phytoplankton (Wildish \& Kristmanson 1979): the greater the turbulence, the greater the rate of supply of phytoplankton to the bed and the less the extent of depletion in the concentration boundary layer. The level of turbulence is itself directly related to current velocity which, in the case of tidal currents, means that reduced turbulence and hence maximum depletion will coincide with slack water.

In this study, we used a combination of biological and physical measurements, including acoustic Doppler current profiler (ADCP) measurements of flow and turbulent stresses, in an effort to clarify the role of both horizontal advection and vertical diffusion in determining the food supply to a large mussel bed system.

\section{Objectives}

The Menai Strait is a narrow channel (20 km long) situated between the Isle of Anglesey and the mainland of Wales. It connects Caernarfon Bay in the south to Liverpool Bay in the northern Irish Sea (Fig. 1) and, because of large differences in the tidal range between the 2 ends of the strait, it experiences strong tidal flows, with velocities of up to $2.5 \mathrm{~m} \mathrm{~s}^{-1}$ during spring tides in the central shallow area (the 'Swellies') and at the SW entrance (Rippeth et al. 2002). This large tidal flow coupled with the shallow water depths (which range from a few metres in the Swellies to $22 \mathrm{~m}$ ) results in rectification of the tidal currents and a net south-

\footnotetext{
${ }^{1}$ Reynolds stress is the force (per unit area) by which a horizontal fluid layer acts on the layer above it in turbulent flow. It is found from the covariance of the horizontal and vertical velocity components $u^{\prime}$ and $w^{\prime}$ as $\left.\rho \overline{\left(u^{\prime} w^{\prime}\right.}\right)$
}

westerly through-flow in the channel that varies between $\sim 330$ and $\sim 800 \mathrm{~m}^{3} \mathrm{~s}^{-1}$ at neap and spring tides respectively (Simpson et al. 1971). The large tidal velocities also induce high levels of turbulence and Reynolds stress ${ }^{1}$, which follow a semidiurnal pattern (Rippeth et al. 2002) with greater stresses during ebb (to $\mathrm{SW}$ ) flow $(\sim 3 \mathrm{~Pa})$ than flood $(\sim 2 \mathrm{~Pa})$. The associated high levels of vertical mixing ensure that the water column is generally well mixed and vertically homogeneous in temperature and salinity.

A substantial area of the NE end of the strait is host to an economically important, commercial mussel bed of Mytilus edulis L. Generally, mussels consume phytoplankton as their primary source of nutrition, and this food source may be produced either locally in the overlying waters or imported. In the case of the Menai Strait, the strong net through-flow implies short residence times for water in the strait ( 2 to $3 \mathrm{~d}$ only), which is too short for accumulation of locally produced biomass. We therefore hypothesise that a high proportion of the food supply to the mussels is carried into the Menai Strait by net transport from Liverpool Bay, which exhibits high concentrations of phytoplankton relative to other areas of the Irish Sea, with a maximum spring biomass of $43.9 \mathrm{mg} \mathrm{m}^{-3}$ in late April (Gowen et al. 2000). If, at the same time, much of the imported phytoplankton is consumed over the mussel beds,

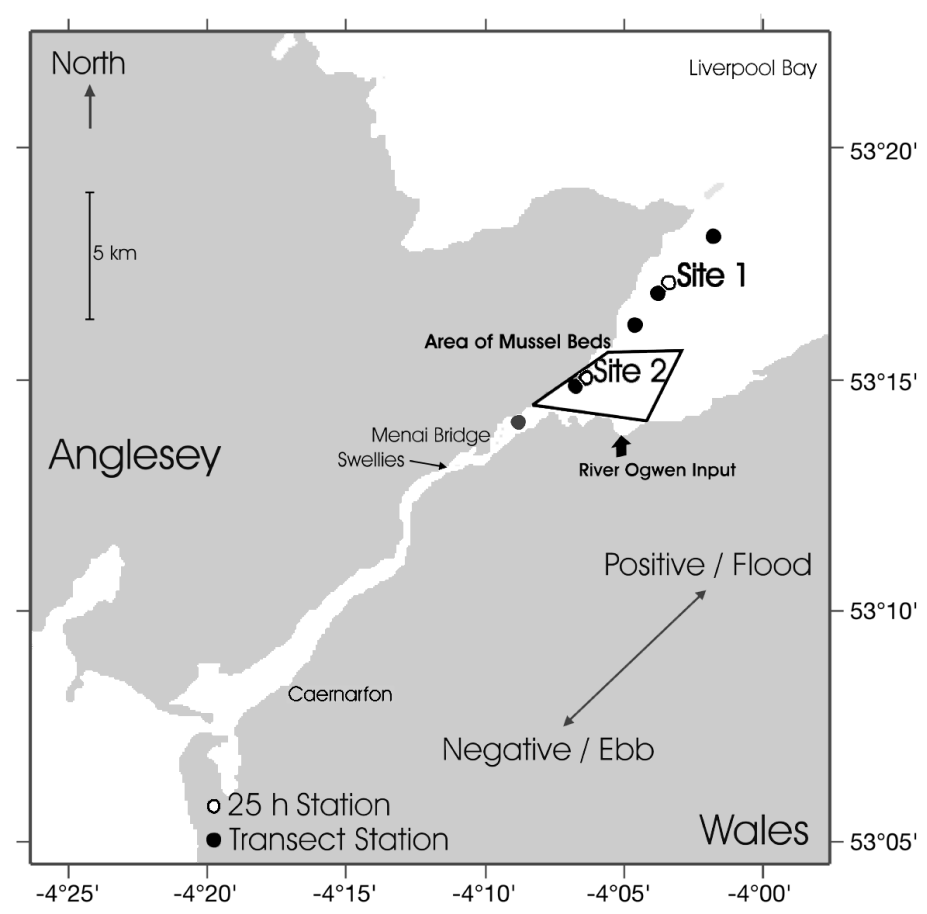

Fig. 1. Menai Strait location and sampling positions. Sites 1 and 2: positions of $25 \mathrm{~h}$ anchor stations; - positions of transect stations; black outline: approximate border of mussel bed area 


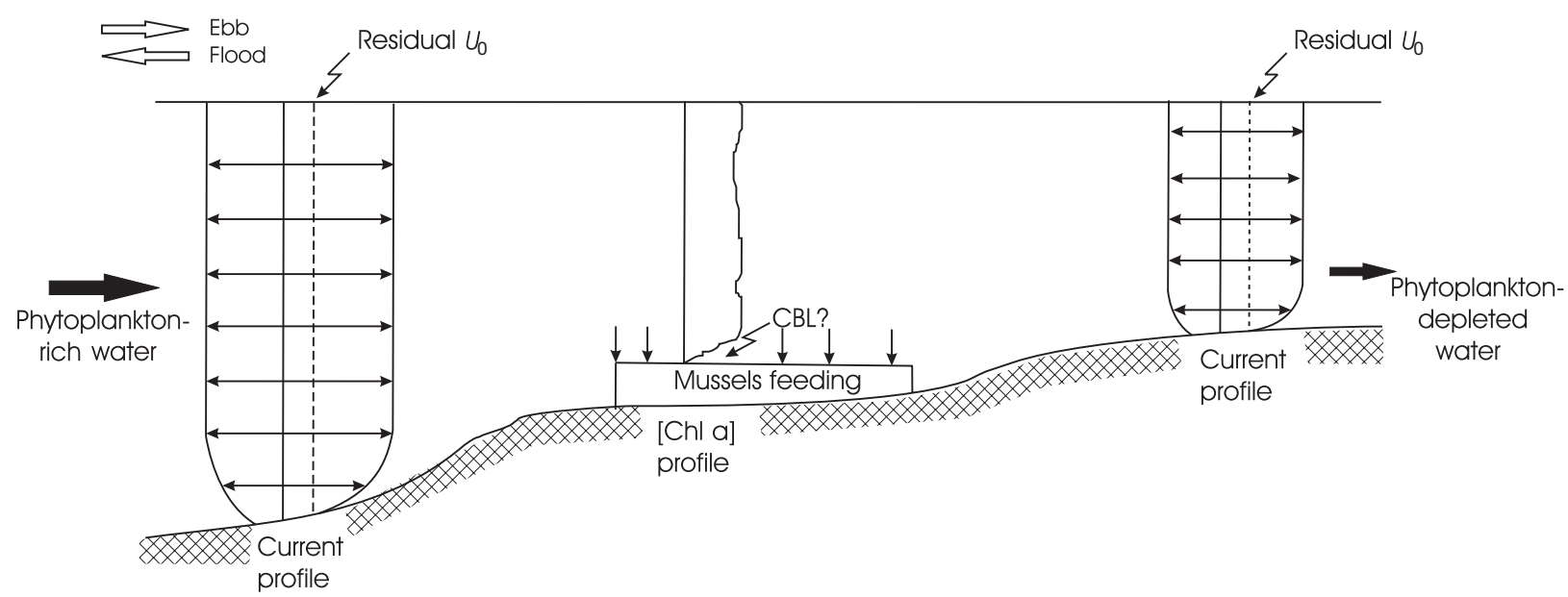

Fig. 2. Simplified tidal and residual flow $\left(U_{0}\right)$ in relation to Menai Strait epifaunal mussel (Mytilus edulis) bed. There is net transport through the channel from NE (left) to SW (right). CBL: chlorophyll boundary layer

there will be a strong mean horizontal concentration gradient along the channel, as indicated in the schematic summary in Fig. 2. Oscillatory advection of this gradient by the tidal flow will, moreover, lead to large local variations in phytoplankton concentration over the tidal cycle. We might also anticipate that, as a result of intensive mussel filtration and variations in vertical mixing, significant vertical gradients of phytoplankton depletion might occur during times of low Reynolds stress in the channel, i.e. during slack water.

It was the aim of our study to investigate the variation in plankton concentration and current profile over the tidal cycle in order to elucidate the relevance of the paradigm of Fig. 2 as a first step towards establishing the balance between horizontal advection, vertical diffusion and consumption of biomass. We attempted to achieve this aim by a combination of time series observations of biomass and physical parameters from an anchored research vessel in parallel with measurements of velocity profiles and turbulence with a seabedmounted ADCP.

\section{MATERIALS AND METHODS}

Two $25 \mathrm{~h}$ data sets were collected during the period 18 to 20 April 2002 (Yeardays [YD] 107 to 109), 1 at each of the 2 positions in Fig. 1, i.e. Site 1 (53 $17.314^{\prime}$ N, $\left.4^{\circ} 03.214^{\prime} \mathrm{W}\right)$ positioned upstream of the mussel beds and Site 2 (53 $\left.15.012^{\prime} \mathrm{N}, 4^{\circ} 06.512^{\prime} \mathrm{W}\right), 4.26 \mathrm{~km}$ from Site 1 along the strait to the SW, over a commercial mussel bed. At each site, the RV 'Prince Madog' was anchored fore and aft and, at 30 min intervals for $25 \mathrm{~h}$, water-column profiles of fluorescence, dissolved oxygen concentration (and percentage oxygen saturation), salinity, temperature and pressure were measured using a SeaBird Electronics CTD (conductivity-temperaturedepth) profiling instrument. Rosette-mounted Niskin bottles were used to collect water samples at $\sim 1 \mathrm{~m}$ above the bed, $\sim 2.5 \mathrm{~m}$ above the bed and $1 \mathrm{~m}$ below the surface during each cast. $500 \mathrm{ml}$ of the collected water was filtered for chlorophyll analysis on GF/F filter paper and stored in a $-70^{\circ} \mathrm{C}$ freezer until extraction with $90 \%$ acetone. Standard protocols for fluorometric pigment concentration analysis were carried out using a Turner Designs 10-AU fluorometer (method adapted from Parsons et al. 1984). A logging Aquatracka (chlorophyll) fluorometer was deployed $1 \mathrm{~m}$ above the seabed on a mooring close to the anchored vessel for $25 \mathrm{~h}$ at each site in order to provide a continuous fluorescence time series. The CTD and in situ fluorometers were calibrated by regression against the CTD water sample chlorophyll concentration.

A bottom-mounted RDI 1.2-MHz Workhorse ADCP was positioned on the seabed at Site 2 for the duration of the experiment to measure the mean and turbulent velocity field. The axis of the ADCP was confirmed to be within $1^{\circ}$ of the vertical so that we were able to apply the variance method (Stacey et al. 1999, Rippeth et al. 2002) for the determination of turbulent shear stress by taking the difference between the variance of opposing beams of an ADCP.

Following completion of the fixed-station observations, CTD profiles were taken on a transect of sites along the Menai Strait (Fig. 1) on YD 120 during ebb flow (to SW), making the same measurements as during the $25 \mathrm{~h}$ stations, to provide an estimate of the along-channel gradient of chlorophyll and other parameters.

A $0.1 \mathrm{~m}^{2}$ Day grab was used to sample the benthos and confirm that there were no mussels or large populations of filter feeders around the area of Site 1. 


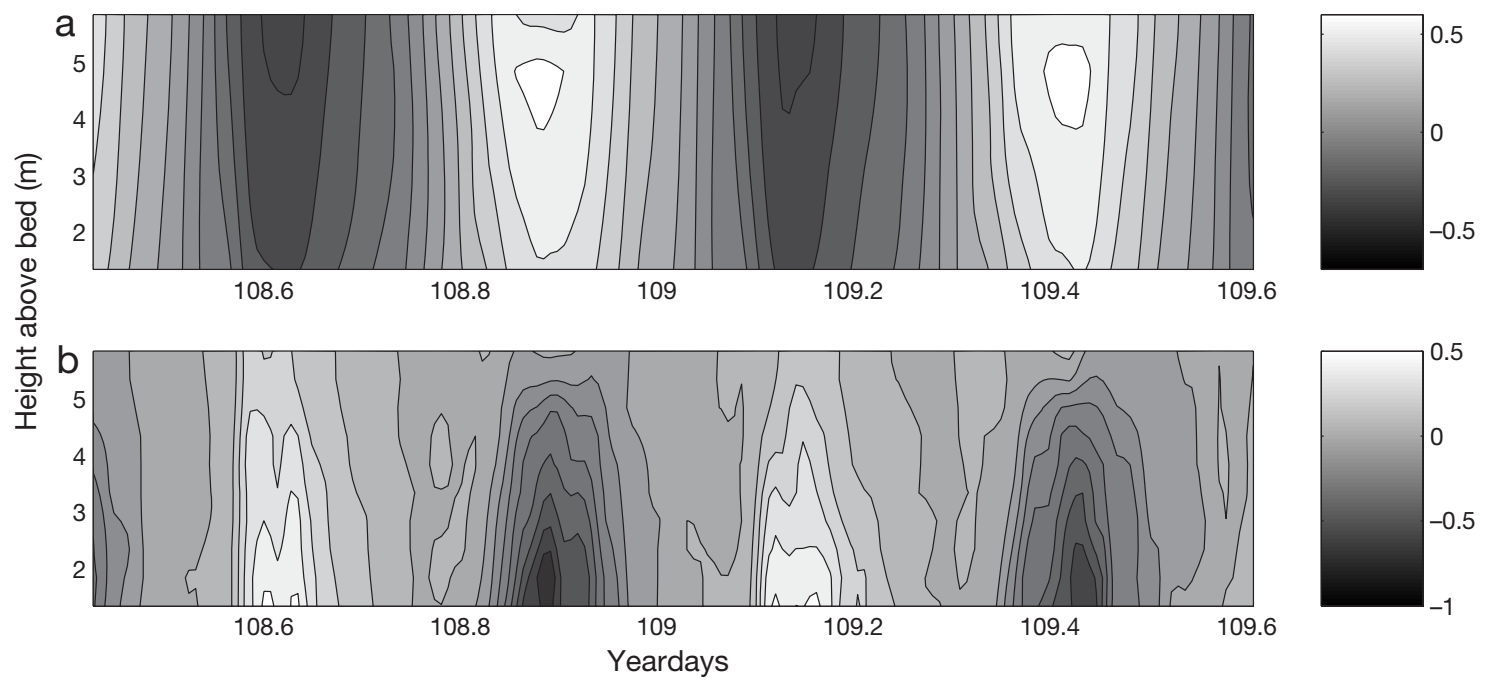

Fig. 3. Acoustic Doppler current profiler (ADCP) $25 \mathrm{~h}$ time series at Site 2. (a) Along-channel velocity (m s${ }^{-1}$ ). (b) Along-channel Reynolds stress $(\mathrm{Pa})$

\section{RESULTS}

\section{Velocity, stress and physical structure}

Data from the bottom-mounted ADCP at Site 2 showed strong semidiurnal variation in the along-strait flow (Fig. 3a), with stronger near-bed velocities (Fig. 4) during flooding to the NE $\left(0.6 \mathrm{~ms}^{-1}\right)$ compared to during the ebb to the SW $\left(-0.5 \mathrm{~m} \mathrm{~s}^{-1}\right)$. In contrast to the velocities, the tidal transport, which is the product of velocity and cross-sectional area, is greater on the ebb than the flood so that there is a net residual to the SW. For YD 105 to 111, this residual transport was estimated from our data as $351 \mathrm{~m}^{3} \mathrm{~s}^{-1}$. In the rather unusual tidal regime of the Menai Strait, the elevation and current are $\sim 180^{\circ}$ out of phase at the Site 2 location so that the greater velocities on the flood coincide with low surface elevations and vice versa; this is equivalent to a progressive wave travelling to the SW. The phasedifference changes along the strait: at Site 1 the tide is close to a standing wave, with northward flow out of the strait starting just before local high water. Fig. 3b shows the Reynolds stress recorded by the ADCP at Site 2. The stress, which is here the force per unit area exerted on the bed, opposes the flow but follows the same semidiurnal pattern; at the bed it has the greatest magnitude at times of maximum speed, and decreases to zero during times of zero velocity (Fig. 4). As with

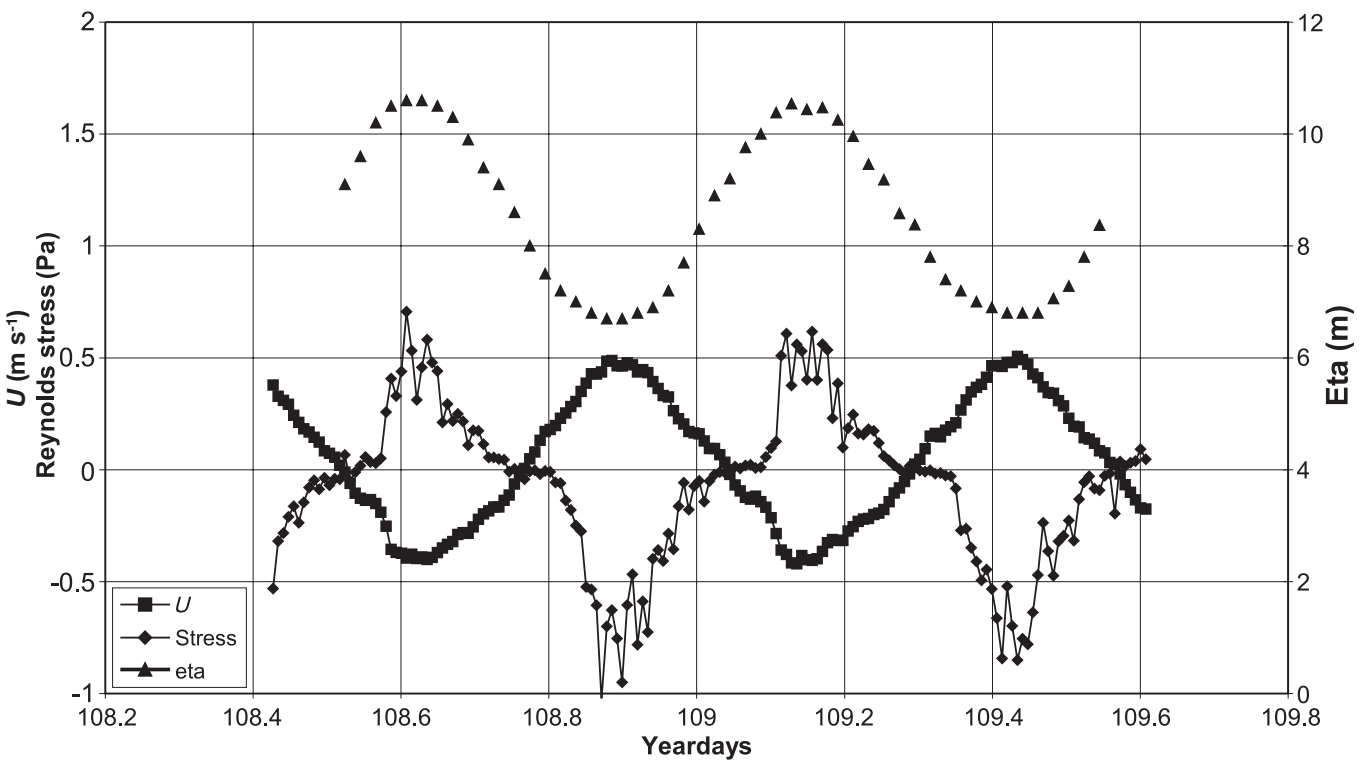

Fig. 4. Cycle of velocity, elevation (eta) and Reynolds stress at Site 2. Velocity $(U)$ is along-channel flow $1 \mathrm{~m}$ above seabed. Reynolds stress $(\mathrm{Pa})$ is along-channel component of stress $1.35 \mathrm{~m}$ above seabed deduced from ADCP measurements via variance method 
the current velocities, the maximum stress values were measured during the flood, in opposition to the usual direction of maximum flow and stress. Campbell et al. (1998) found that strong SW winds may cause a reversal in the direction of the residual flow to the NE.

The current profiles measured at Site 2 showed strong velocities extending from the surface to the bed of the water column, with high Reynolds stresses reaching to near the surface for less extended periods of time. Our time series of temperature, salinity and the derived density (Figs. $5 \& 6$ ) support this indication of complete mixing throughout the tidal cycle, with only rather small changes in time in the vertical mixed properties. The largest change in density occurs at Site 1, due to a drop in salinity of about 1 PSU which follows soon after low water when the flow is to the NE, it seems likely that it represents the effect of freshwater input from the River Ogwen, which enters at the NE end of the strait (Fig. 1). At Site 2, a smaller drop in salinity of around 0.4 PSU coincides with times of low Reynolds stress and slack water, and appears again to be due to the influence of the River Ogwen, which flows into the strait near Site 2. During times of low tidal current velocities the freshwater will pool, before being carried away and mixed in with the strait water when currents increase.

\section{Chlorophyll time series}

The calibrated CTD fluorometer data from Site 1 (Fig. 5d) revealed chlorophyll a ( $\mathrm{chl} \mathrm{a)} \mathrm{concentrations}$ of approximately $6 \mu \mathrm{g} \mathrm{l}^{-1}$, apart from 2 distinct decreases in pigment when concentrations fell to approximately $2 \mu \mathrm{g} \mathrm{l}^{-1}$ at YD 107.89 and YD 108.41. These 2 periods of reduced pigmentation occurred $\sim 12.5 \mathrm{~h}$ apart, with the minima coinciding with the maximum NE displacement by the flow. The water samples and moored fluorometer data confirmed this pattern of chl a concentration at Site 1, with pronounced decreases (by a factor of 2 or more) separated by $12.5 \mathrm{~h}$.

The chl a cycle at Site 2 (Fig. 6d) also showed a semidiurnal cycle, with maxima of $\sim 5.5 \mu \mathrm{g} \mathrm{l}^{-1}$ at YD 108.65 and YD 109.18. These maxima, which were somewhat lower than those at Site 1, were almost coincident with the time of greatest current flow to the SW, and of about $4 \mathrm{~h}$ duration. Between these peaks, the chl a level was substantially lower, with values $\sim 3 \mathrm{~g} \mathrm{l}^{-1}$. We interpret the fact that chl a was generally higher on the ebb than on the flood as being primarily due to tidal advection, as ebb flow brings plankton-richer water from the strait's northern entrance to the mussel site, while on the flood, well filtered plankton-depleted water, which has been in
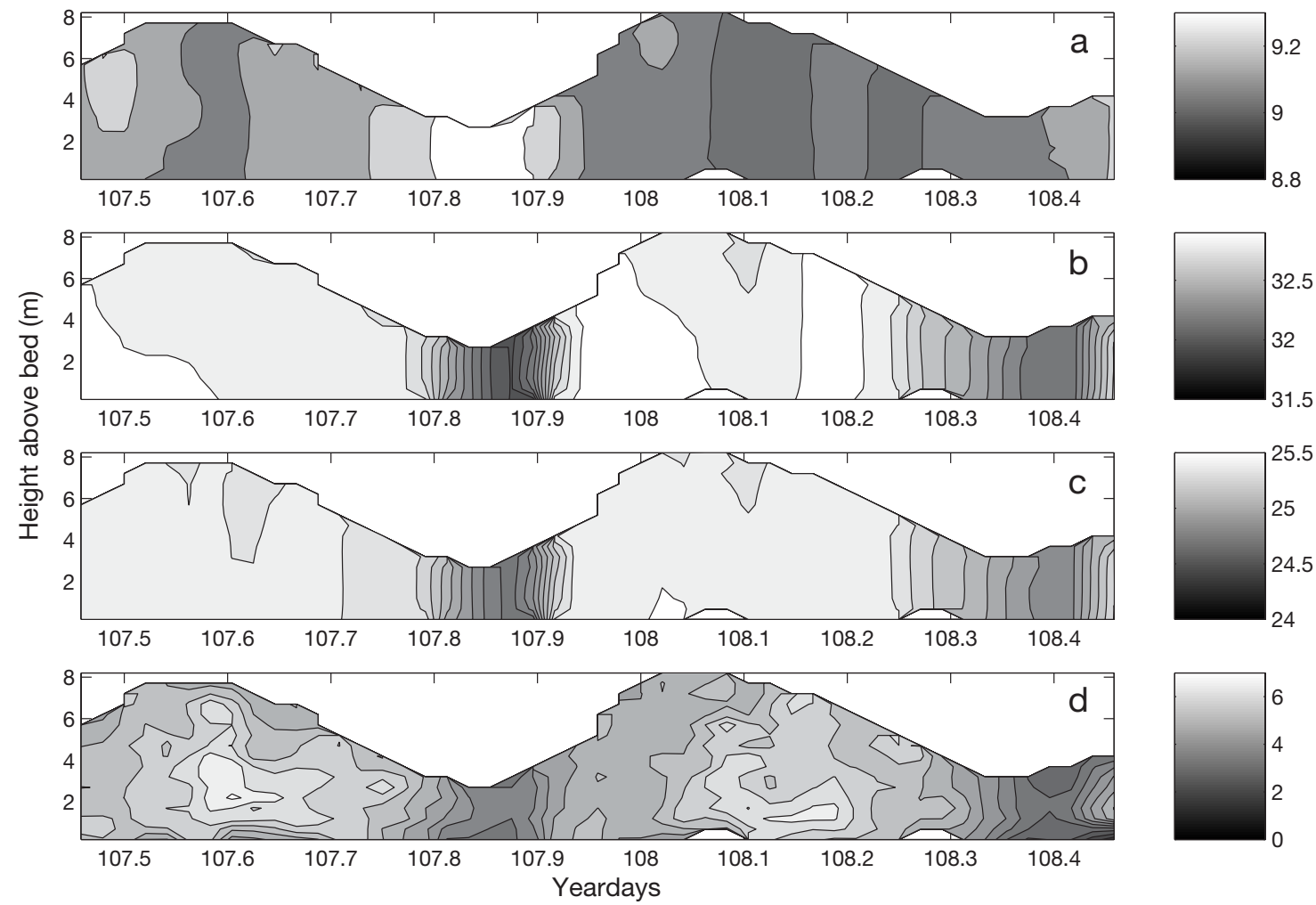

Fig. 5. CTD $25 \mathrm{~h}$ time series at Site 1. (a) Temperature $\left({ }^{\circ} \mathrm{C}\right) ;\left(\right.$ b) salinity; (c) water density $\left(\sigma_{\mathrm{t}}\right)$; (d) chl a from fluorescence $\left(\mu \mathrm{g} \mathrm{l}^{-1}\right)$ 


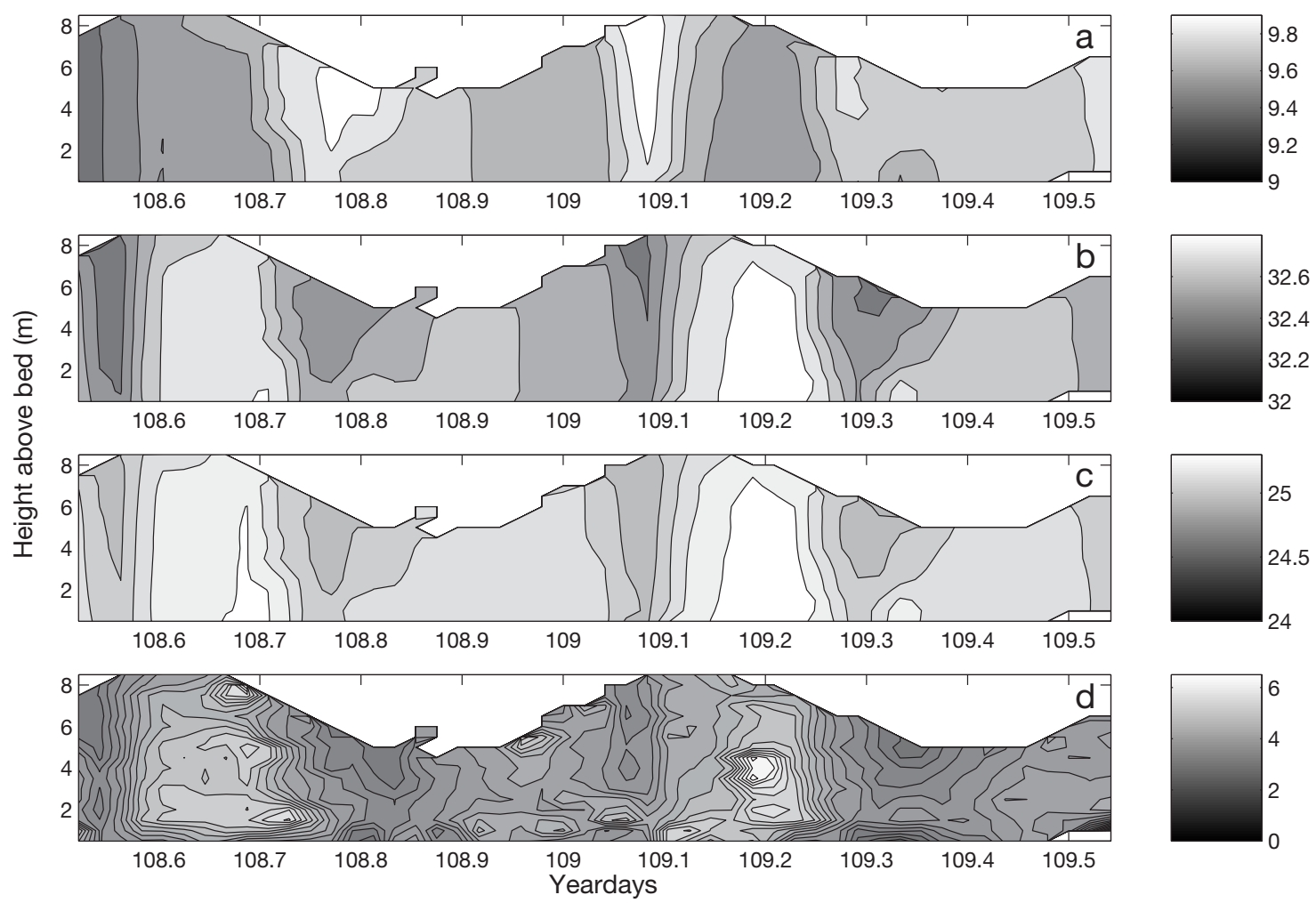

Fig. 6. CTD $25 \mathrm{~h}$ time series at Site 2. (a) Temperature $\left({ }^{\circ} \mathrm{C}\right) ;(\mathrm{b})$ salinity; (c) water density $\left(\sigma_{\mathrm{t}}\right) ;(\mathrm{d})$ chl a from fluorescence $\left(\mu \mathrm{g} \mathrm{l}^{-1}\right.$ )

the strait longer, moves to the NE from the inner part of the strait. Fig. 7 shows clearly the higher chlorophyll values associated with ebb as opposed to flood tide. The displacement value represents how far the water was from Site 2 when the tide turned and thus how far it had to travel before passing Site 2. Larger flood displacement values mean the water was further downstream over the mussel bed and had possibly been subjected to more filtering; decreased chlorophyll values are correlated with the water that travelled furthest over the mussel beds.

As with salinity, at Site 2 chlorophyll concentration decreased slightly at slack water, which is consistent with an input of River Ogwen water with lower production.

Standard ANOVA tests (using $\alpha=0.05$ ) were used to calculate statistical differences between concentration measurements.It was found that Site 2 had statistically lower mean concentrations of chl a $\left(\mathrm{p}<0.05, f_{\text {crit }}=3.85\right.$, $f=263.50$ for the moored data) than Site 1 over a tidal cycle, at all water depths measured. The horizontal gradient was calculated using the mean values of chlorophyll concentration $\left(\mathrm{chl}_{1}\right.$ and $\left.\mathrm{chl}_{2}\right)$ over a $12.5 \mathrm{~h}$ tidal cycle as:

$$
\frac{\partial \mathrm{chl}}{\partial x}=\frac{\mathrm{chl}_{1}-\mathrm{chl}_{2}}{\Delta x}
$$

with $\Delta x$ being the distance between sites. This yields horizontal gradient estimates of $4.8 \times 10^{-4} \mathrm{~g} \mathrm{~g}^{-1} \mathrm{~m}^{-1}$ near the bed and $4.4 \times 10^{-4} \mu \mathrm{g} \mathrm{l}^{-1} \mathrm{~m}^{-1}$ at $1 \mathrm{~m}$ below the surface.

A second independent estimate of the chlorophyll gradient was obtained from the along-channel transect survey with the CTD system (for station positions see Fig. 1). The plot of chl a concentration (Fig. 8), taken during ebb flow along the axial transect, revealed an overall decrease of chl a going SW into the Menai Strait. The corresponding vertical mean horizontal gradient was $4.28 \times 10^{-4} \mu \mathrm{g} \mathrm{l}^{-1} \mathrm{~m}^{-1}$, which is comparable to the gradient estimate from the means at the 2 sites. If the gradient is calculated from where the concentration begins to drop at CTD cast (Fig. 8) to the end of the transect (representing the gradient purely over the mussel bed) the vertical mean horizontal gradient increases to $6.89 \times 10^{-4} \mathrm{\mu g} \mathrm{l}^{-1} \mathrm{~m}^{-1}$.

\section{Depletion near the bed}

To investigate the possible depletion of phytoplankton concentration near the bed, we examined differences in chl a concentration between 2.5 and $1 \mathrm{~m}$ above the bed: Depletion $=[\mathrm{chl} \mathrm{a}]_{2.5 \mathrm{~m}}-[\mathrm{chl} \mathrm{a}]_{1 \mathrm{~m}}$, which is plotted in Fig. 9. Statistically significant levels of depletion 


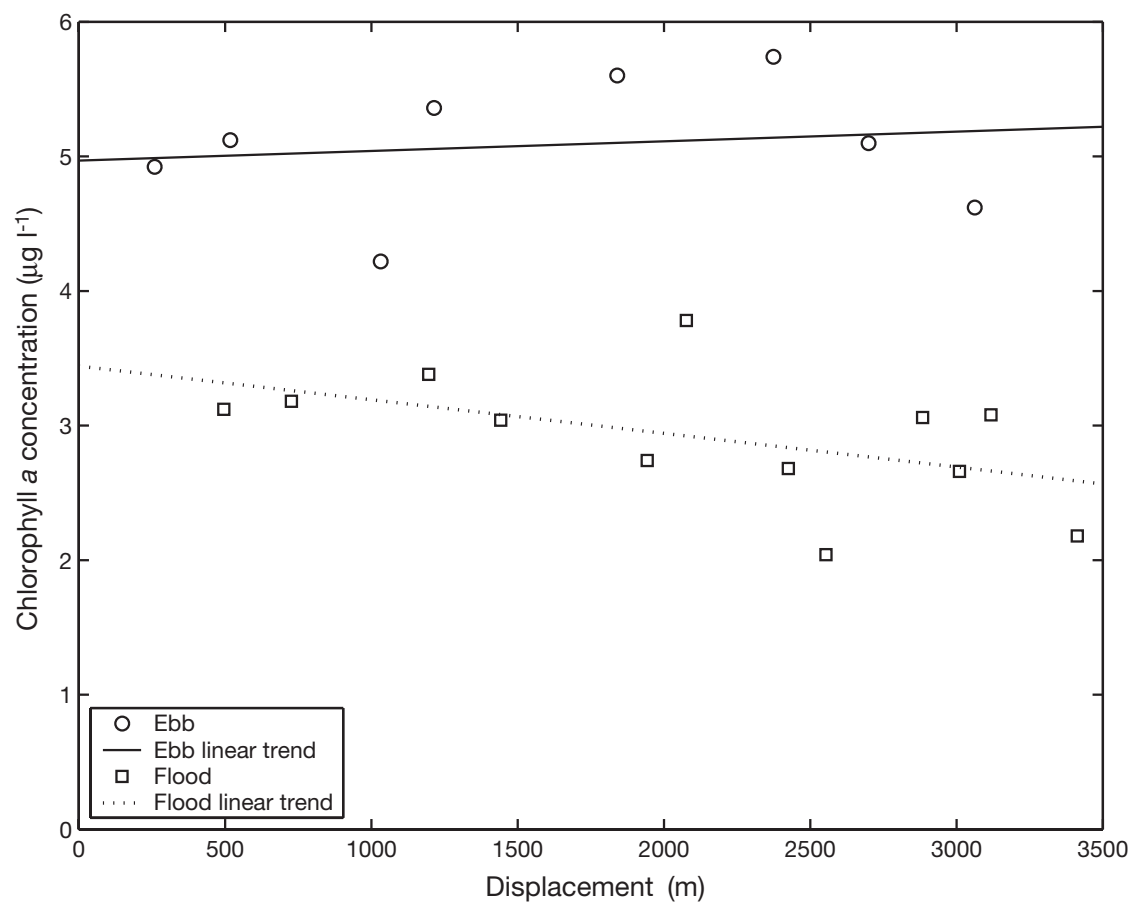

Fig. 7. Chl a concentration plotted against displacement from Site 2. Displacement denotes how far each parcel of water has travelled since previous switch in velocity direction, before being measured at Site 2 . Water was measured (O) on ebb flow (to SW), and ( $\square$ ) on flood flow (to NE)

( $>2$ SD from the mean) occurred twice in the sampling period at Site 2, in adjacent samples at YD 108.5208 and 108.5417, and again at YD 109.3125 (Fig. 9). Depletion values calculated for the 2 CTD bins closest to the bed (generally 0.5 and $1 \mathrm{~m}$ above the bed) showed statistically significant depletion at YD 108.5208 and 109.0625. These depletion events occurred during periods of slack water when levels of Reynolds stress (also shown in Fig. 9) were negligible. We interpret these periods of high near-bed gradients as being the result of mussel filtration briefly out-competing the vertical flux of plankton, which is limited by the low levels of turbulence. Short periods of depletion above the bed at Site 1 were seen in the CTD data immediately after slack water, but were attributable to tidal straining.

Conversely, statistically significant increased levels of chlorophyll at the bed $(<2 \mathrm{SD}$ from the mean) occurred only once at Site 2, at YD 108.8542 in the CTD depletion values. This corresponded to a time of peak Reynolds stress and is interpreted as resuspension of material from the bed of the strait.

\section{Advection-filtration model}

We can represent the essential interaction between horizontal flow and mussel feeding as a local competi- tion between supply by advection and consumption by filtration. Assuming that concentrations are uniform vertically and that the flow is in the along channel $\mathrm{x}$ direction, we have for the rate of change of chl a concentration, c

$$
\frac{\partial c}{\partial t}=-U \frac{\partial c}{\partial x}-\lambda c
$$

where $\lambda$ is the net consumption rate due to filtration by the mussels plus pelagic grazing minus local phytoplankton production, and $U$ is the flow rate which is a combination of a residual flow $U_{0}$ and a tidal oscillation of amplitude $U_{2}$ given by:

$$
U=U_{0}+U_{2} \sin (\omega t)
$$

where $\omega$ is the tidal frequency.

If the chlorophyll gradient $\mu=\partial \mathrm{c} / \partial \mathrm{x}$ is assumed constant in time, we can integrate Eq. (2) to give $C$ as a function of time $t$ :

$$
C(t)=-\frac{\mu U_{0}}{\lambda}-\frac{\mu U_{2}}{\sqrt{\lambda^{2}+\omega^{2}}} \sin (\omega t-\phi)
$$

where $\tan \phi=\omega / \lambda$. This solution represents a mean concentration together with a tidal oscillation. Using the observed gradient

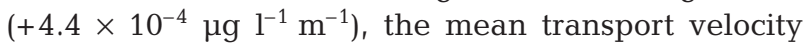
$\left(-0.15 \mathrm{~m} \mathrm{~s}^{-1}\right)$ and the average value over 2 tidal cycles of $c=3.65 \mathrm{\mu g} \mathrm{l}^{-1}$ at Site 2, we can estimate the consumption rate as $\lambda=1.8 \times 10^{-5} \mathrm{~s}^{-1}$ which corresponds to benthic filtration rate $(f)$ of $f=\lambda h=1.3 \times 10^{-4} \mathrm{~m} \mathrm{~s}^{-1}$, where $h$ is water depth. For a tidal velocity amplitude of $0.5 \mathrm{~m} \mathrm{~s}^{-1}$, the tidal cycle of $C$ should, according to Eq. (4) have an amplitude of $\sim 1.4 \mu \mathrm{g} \mathrm{l}^{-1}$, which is close to that observed. The model is less successful in relation to the phase-lag where the observations correspond to a larger value of $\lambda$, indicating a limitation in the simplifying assumptions used; in particular, the prescription of a fixed-time invariant gradient is not realistic.

\section{DISCUSSION}

The principal inference from our observations is that consumption of phytoplankton by filtration over a mussel bed in the Menai Strait reduces water-column concentrations and results in a pronounced horizontal gradient. Losses to filtration over the mussel bed are compensated by transport of plankton into the strait by the large residual flow ( 350 to $800 \mathrm{~m}^{3} \mathrm{~s}^{-1}$ ). Advection of the gradient by the tidal current results in large oscilla- 


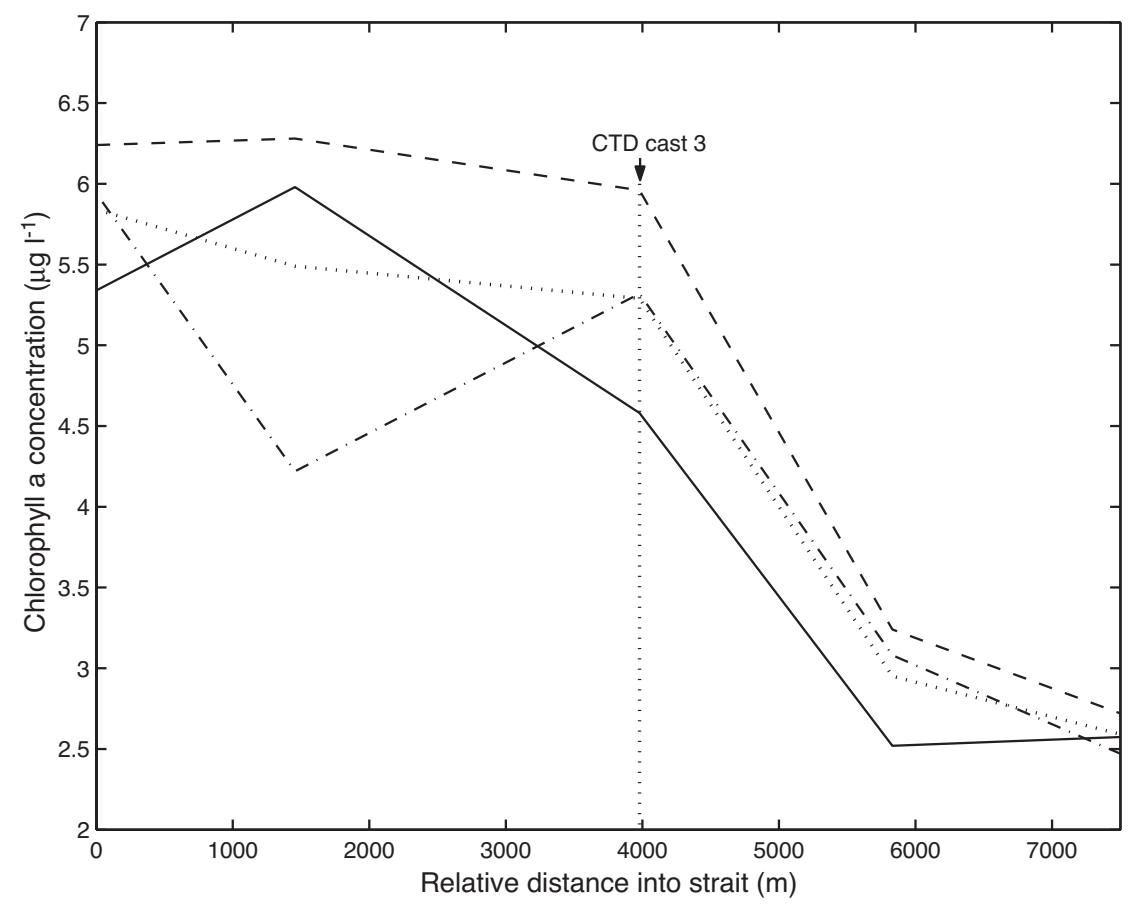

Fig. 8. Chl a concentration along Menai Strait axial section from CTD profiles at stations shown in Fig. 1 on Yearday 120 during ebb flow (to SW) at $1 \mathrm{~m}$ below surface (- $), 2.5 \mathrm{~m}$ above seabed $(---), 1 \mathrm{~m}$ above seabed $(-\cdot-\cdot-)$. ............ : vertically averaged values

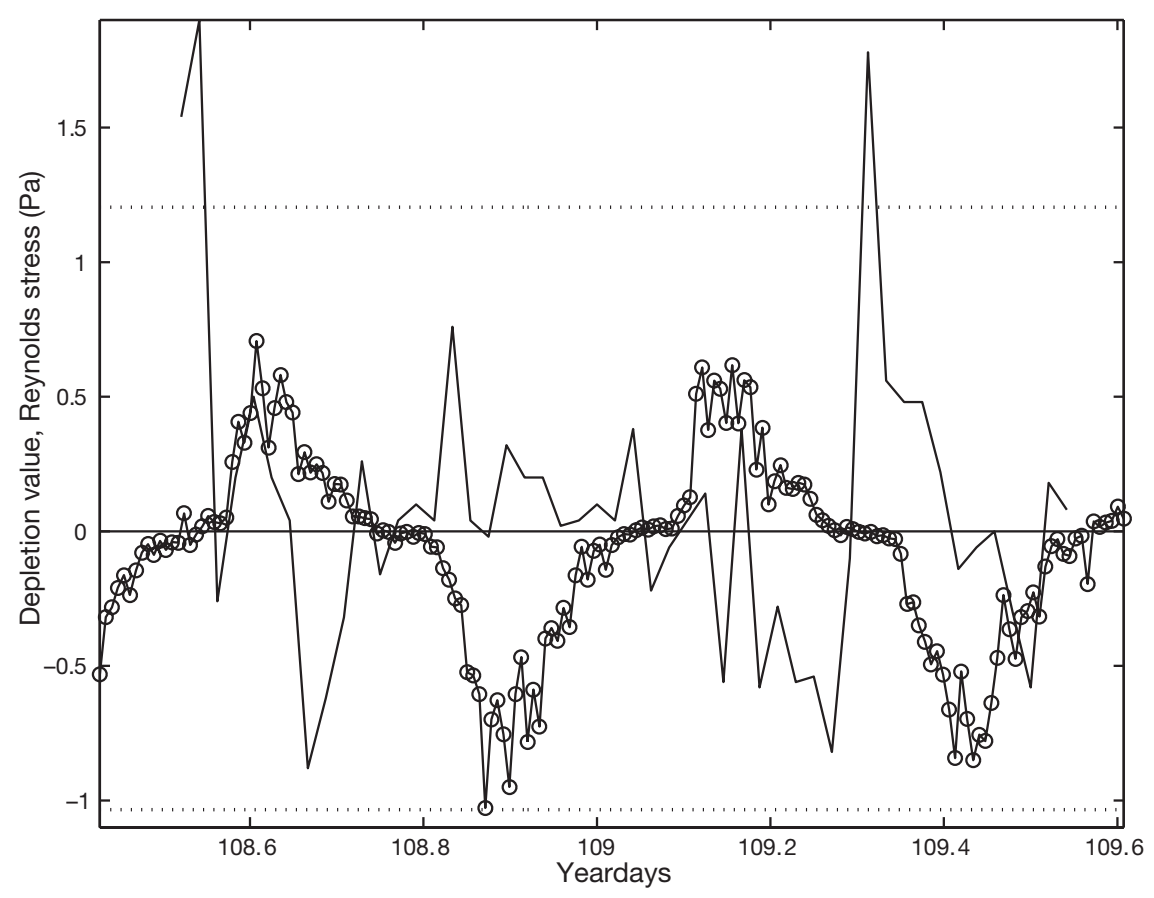

Fig. 9. Chl a differences between 1 and $2.5 \mathrm{~m}$ above seabed ( - ) together with Reynolds stress $1.4 \mathrm{~m}$ above seabed (○- $)$ ). ............ level 2 SD above mean difference, calculated over $25 \mathrm{~h}$ tions of chl a concentration, with an amplitude of $\sim 50 \%$ of the mean. These oscillations were observed both at a site over the mussel beds and at a control site where there were no mussels and phytoplankton-depleted water was present for only a relatively short period during the tidal cycle.

At most times, the distribution of phytoplankton was uniform vertically on account of the strong tidal stirring in the strait. Marked depletion in the nearbed layer was observed only during 2 episodes at the mussel bed site, both when the Reynolds stress was zero at slack water. It may be concluded therefore that limitation of food supply by the development of concentration boundary layers is not significant in the present situation. We interpret the lack of any signs of depletion at Site 1 as being due to the lack of consumption, as there were no mussels present to remove phytoplankton close to the bed. Although marked depletion was observed during 2 low stress events at Site 2 , there was no comparable signal during 2 other low stress periods. This may have been due to sampling limitations, for example the depleted layer not extending to $1 \mathrm{~m}$ above the bed (Wildish \& Kristmanson 1984, Fréchette \& Bourget 1985, Fréchette et al. 1989, Riisgård et al. 1996) or occurring between 2 of the half-hourly CTD casts. More frequent sampling, closer to the bed, would increase the likelihood of observing concentration boundary layers, and allow better estimates of the time and size scales of depletion. Future studies might also take into account the influence of the suspension and settling of benthic algae, which Thompson (1999) found could result in underestimation of a concentration boundary layer by reducing the depth to which the layer extended.

The horizontal gradient in chl a concentration was determined to be $\sim 4.6 \times$ $10^{-4} \mathrm{\mu g} \mathrm{l}^{-1} \mathrm{~m}^{-1}$ by taking the difference between tidally averaged means at the 2 stations and also by an along-channel transect of stations. Similar gradients have been found previously over mussel beds (Norén et al. 1999) and 
coral reefs (Yahel et al. 1998, Fabricius \& Dommisse 2000), where phytoplankton abundance was lower over the reefs than away from them. Wildish \& Kristmanson (1984) and Smaal \& Haas (1997) previously suggested that mussel bed filtration and consumption could lead to gradients in concentration of phytoplankton. The present study has shown how the interaction between consumption and horizontal advection generates and maintains the horizontal gradient. We also incorporated the gradient estimates into a simple analytical model of the advection-filtering competition. The solution exhibited qualitatively similar behaviour to the observations with tidal oscillations of the correct magnitude, and allowed an estimate of the benthic filtering rate $f$ of an order of $1.3 \times 10^{-4} \mathrm{~m} \mathrm{~s}^{-1}$. For a mean depth of $7 \mathrm{~m}$ this corresponds to a filtration time for the whole water column of $\sim 15 \mathrm{~h}$ at Site 2 .

Our data can also be used to make a rough estimate of the total available food supply entering the strait in the mean flow, on the assumption that the observed gradients represent an approximately steady state condition for the spring regime in the strait. Taking the mean transport through the channel $(\bar{Q})$ as $500 \mathrm{~m}^{3} \mathrm{~s}^{-1}$, and the average concentration of chlorophyll $(c)$ entering from the NE, we have for the flux $(F)$ of carbon (biomass) into the strait:

$F_{\mathrm{c}}=\gamma \bar{Q}_{C}=35 \times 500 \times 6=105 \mathrm{~g} \mathrm{~s}^{-1}=9.07 \mathrm{t}_{\text {carbon }} \mathrm{d}^{-1}$

where $\gamma$ is the carbon:chl a ratio for phytoplankton. Since concentration falls by a factor of 2 between the NE entrance and Menai Bridge, we infer that around half of this biomass flux, i.e. a net $4.5 \mathrm{t}_{\text {carbon }} \mathrm{d}^{-1}$ is removed over the mussel beds.

Integration of estimates of the instantaneous carbon flux over the carbon cycle based on the velocity and chlorophyll data from Site 2 (Fig. 4) indicates a net carbon flux of $\sim 6 \mathrm{t} \mathrm{d}^{-1}$ during a period when the net flux of water was $\sim 320 \mathrm{~m}^{3} \mathrm{~s}^{-1}$.

These measurements are among the first over mussel beds to include the determination of Reynolds stresses by the ADCP variance method. While the use of the stress data here has been limited to $>1 \mathrm{~m}$ above the seabed, we have demonstrated the viability of such direct measurements of stress and now foresee considerable potential for future use, whilst developing methods to make these measurements closer to the bed. According to Butman et al. (1994), turbulence is increased up to 10 times over mussels in a laboratory flume compared to a hydraulically smooth bed, and there is clearly scope to investigate such effects by comparison between different sites and between different stages of mussel development at the same site. There is an interesting possibility that the mussels themselves may be limiting the development of concentration boundary layers by increasing turbulent transport to the bed through both mixing induced by the mussels' exhalent jets (Larsen \& Riisgård 1997) and by increasing the roughness length of the bed with their shells.

Acknowledgements. We would like to thank L. M. Ribes for her calculations on the volume transport through the Menai Strait. Thanks also to E. Williams for her assistance with the ADCP processing, to V. Ellis for all her help in the laboratory work, and to the Captain and crew of the RV 'Prince Madog II'. This study was supported in part by funding from EU Framework V MaBenE EVK3-2001-00144.

\section{LITERATURE CITED}

Ackerman JD (1999) Effect of velocity on the filter feeding of dreissenid mussels (Dreissena polymorpha and Dreissena bugensis): implications for trophic dynamics. Can J Fish Aquat Sci 56:1551-1561

Ackerman JD, Loewen MR, Hamblin PF (2001) Benthicpelagic coupling over a zebra mussel reef in western Lake Erie. Limnol Oceanogr 46:892-904

Butman CA, Fréchette M, Geyer WR, Starczak VR (1994) Flume experiments on food supply to the blue mussel Mytilus edulis L. as a function of boundary-layer flow. Limnol Oceanogr 39:1755-1768

Campbell AR, Simpson JH, Allen GL (1998) The dynamical balance of flow in the Menai Strait. Estuar Coast Shelf Sci 46:449-455

Cloern JE (1982) Does the benthos control phytoplankton biomass in south San Francisco Bay? Mar Ecol Prog Ser 9: 191-202

Cohen RRH, Dresler PV, Phillips EJP, Cory RL (1984) The affect of the Asiatic clam, Corbicula fluminea, on phytoplankton of the Potomac River, Maryland. Limnol Oceanogr 29:170-180

Fabricius KE, Dommisse M (2000) Depletion of suspended particulate matter over coastal reef communities dominated by zooxanthellate soft corals. Mar Ecol Prog Ser 196: 157-167

Fréchette M, Bourget E (1985) Energy flow between the pelagic and benthic zones: factors controlling particulate organic matter available to an intertidal mussel bed. Can J Fish Aquat Sci 42:1158-1165

Fréchette M, Butman CA, Geyer WR (1989) The importance of boundary-layer flows in supplying phytoplankton to the benthic suspension feeder, Mytilus edulis L. Limnol Oceanogr 34:19-36

Gowen RJ, Mills DK, Trimmer M, Nedwell DB (2000) Production and its fate in two coastal regions of the Irish Sea: the influence of anthropogenic nutrients. Mar Ecol Prog Ser 208:51-64

Larsen PS, Riisgård HU (1997) Biomixing generated by benthic filter feeders: a diffusion model for near-bottom phytoplankton depletion. J Sea Res 37:81-90

Norén F, Haamer J, Lindahl O (1999) Changes in the plankton community passing a Mytilus edulis mussel bed. Mar Ecol Prog Ser 191:187-194

O'Riordan CA, Monismith SG, Koseff JR (1993) A study of concentration boundary-layer formation over a bed of model bivalves. Limnol Oceanogr 38:1712-1729

Parsons TR, Maita Y, Lalli CM (1984) A manual of chemical and biological methods for seawater analysis. Pergamon Press, Oxford

Riisgård HU, Poulsen L, Larsen PS (1996) Phytoplankton reduction in near-bottom water caused by filter-feeding 
Nereis diversicolor-implications for worm growth and population grazing impact. Mar Ecol Prog Ser 141:47-54

Rippeth TP, Williams E, Simpson JH (2002) Reynolds stress and turbulent energy production in a tidal channel. J Phys Oceanogr 32:1242-1251

Simpson JH, Forbes AMG, Gould WJ (1971) Electromagnetic observations of water flow in the Menai Straits. Geophys J R Astron Soc 24:245-253

Smaal AC, Haas HA (1997) Seston dynamics and food availability on mussel and cockle beds. Estuar Coast Shelf Sci 45:247-259

Stacey MT, Monismith SG, Burau JR (1999) Measurements of Reynolds stress profiles in unstratified tidal flow. J Geophys Res C 104:10933-10949

Thompson JK (1999) The effect of infaunal bivalve grazing on phytoplankton bloom development in south San Francisco

Editorial responsibility: Otto Kinne (Editor-in-Chief), Oldendorf/Luhe, Germany
Bay. PhD thesis, Stanford University, Stanford

Wildish DJ, Kristmanson DD (1979) Tidal energy and sublittoral macrobenthic animals in estuaries. J Fish Res Board Can 36:1197-1206

Wildish DJ, Kristmanson DD (1984) Importance to mussels of the benthic boundary layer. Can J Fish Aquat Sci 41: $1618-1625$

Wolff WJ, Vegter F, Mulder HG, Meijs T (1975) The production of benthic animals in relation to the phytoplankton production. Observations in the saline Lake Grevelingen, The Netherlands. In: Persoone G, Jaspers E (eds) Proceedings of the 10th European symposium on marine biology, Vol 2. Universa Press, Wetteren, p 653-672

Yahel G, Post AF, Fabricius K, Marie D, Vaulot D, Genin A (1998) Phytoplankton distribution and grazing near coral reefs. Limnol Oceanogr 43:551-563

Submitted: October 24, 2003; Accepted: October 12, 2004 Proofs received from author(s): March 11, 2005 